\title{
Social laboratories as a method of testing solutions to the problems of post-release prisoner assistance in Poland - A case study of the activities of the 'Mateusz' Association for Prevention and Rehabilitation (Stowarzyszenie Profilaktyki i Resocjalizacji „Mateusz”)
}

\begin{abstract}
The Polish post-release assistance system for prisoners suffers from multiple dysfunctions, such as formalization, excessive bureaucracy, low flexibility, and a chronic shortage of funds. Attempts have been made to solve these issues by departing from a standard set of measures, introducing changes to the funding mechanism, improving personnel training, and ensuring a higher level of openness to more innovative measures. The first part of this paper describes the operations of the 'Mateusz' Re-adaptation Centre in Torun, with a special focus on the 'Dąbrowski method' and on positive adaptation, which constitute the basis of the Centre's activities and are referred to as 'initial post-release prisoner assistance.' The second part of the paper presents the concept of social laboratories, through which the theoretical concepts of 'resilience' and 'empowerment' will be used
\end{abstract}

${ }^{1}$ Correspondence: Institute of Sociology, Nicolaus Copernicus University, ul. Fosa Staromiejska 1a, 87-100 Toruń, author's email address: crispiat@umk.pl 
to conduct a two- or three-year-long research at the Centre to prepare a proposal for reforming the Polish post-release assistance system and ensure improved flexibility, beneficiary empowerment and, above all, greater effectiveness in the rehabilitation process.

Key words: post-release assistance, 'Mateusz' Re-adaptation Centre, positive adaptation, 'resilience', 'empowerment', social laboratory

\section{Introduction}

Applied (or engaged) sociology, which, alongside social policy understood as an area of science, aims at using social theories and the research methodologies of social sciences to shape society, and in particular to solve 'burning' or important social problems. This paper highlights an example of such a situation, and, by pointing to the institution of social laboratories, shows how the theories and social concepts of 'resilience' and 'empowerment' can be used to identify the causes of pathologies (e.g., alcoholism), propose an effective tool for treating such disorders in the rehabilitation process (the 'Mateusz' Re-adaptation Centre), and, as a result, create a modern system of post-release assistance in Poland.

\section{The basic dysfunctions in the public post-release assistance process - an important element of social assistance in Poland - and the methods of combatting them}

Social assistance in the broad and colloquial sense is understood as a catalogue of goods (financial benefits and/or benefits in kind) and services provided by the relevant organizations to individuals who need help (Kaźmierczak, 2000, p. 144). From a professional perspective, it is part of the social security system's care technique, the sources of which emanate from interventionist social policy, which is in turn based on the belief that the occurring social tensions need to be defused. These tensions are usually the result of a failure to satisfy financial social needs, and defusing them is possible only by initiating adequate social activities, adopting appropriate procedures as stipulated in legal regulations, and applying diverse measures aimed at changing the situation (Szumlicz, 2002, pp. 117-125).

The system of social assistance currently in place in Poland has been developed over the last thirty years in the process of transforming the political and economic system, and is based on clear structures and organizational principles, specific mechanisms of funding, personnel and knowledge resources, and European experiences. In recent years, however, multiple weaknesses in this system have been exposed, and a number of experts have called for radical changes, as can be illustrated in the following statement by Marek Rymsza: "after the fundamental stage of political transformation, the Polish social assistance system requires, a reorientation from protective measures to measures that 
activate the support beneficiaries. Put simply, this speaks in support of an appreciation of social work" (Rymsza, 2010, p. 157).

Part of the broad area of social assistance in Poland is the system of post-release assistance, which primarily targets individuals who have just been released from prison, but also encompasses their families, as well as social organizations and institutions that play a crucial role in the process of social reintegration. The problems hindering the optimal functioning of the post-release assistance system, as with the entire social assistance system in Poland, stem from the historical background (e.g., the socialism legacy, primacy of central over local administration, a dearth of local government institutions, the principle of full employment implemented in a formalist manner, redistributive paternalism, etc.), but they are also a consequence of the huge scale of crisis- and transformation-related problems that have existed over the last thirty years.

Due to the weakness of the Polish civic sector and a virtual lack of third-sector organizations in the area of post-release assistance, the inefficiency of this system in Poland is mainly the result of the dysfunctions of the public post-release assistance system. These dysfunctions are manifested in the excessive formalization of activities, the high level of bureaucracy, the chronic shortage of funds, and insufficient flexibility, as well as in the inadequate quality of inter-sectoral and inter-institutional cooperation. The ultimate consequence of these dysfunctions is the low effectiveness of the post-release assistance system in Poland, as a result of which the recidivism (re-incarceration) rate in recent years has been relatively high - around 50 per cent. This means that around half of the individuals serving time in prison can be expected to be incarcerated again; in 2018, it was almost exactly 50 per cent (Służba Więzienna, 2018).

It is hard to imagine an effective fight against the inefficiencies of the Polish postrelease assistance system without a gradual departure from a standard set of measures regarding public social assistance mechanisms. This process should include creating conditions for a better understanding of the relevant social and professional roles by the beneficiaries of social assistance, and in the case of individuals released from prison, changing the funding structure to improve flexibility, and identifying new forms and methods of work organization in prisons, so that there can be a more effective cooperation between prison officers and social services. It is extremely important to methodically introduce activating measures, especially by activating and organizing NGOs and local communities for the purpose of solving social problems (Trawkowska, 2010, pp. 186-187).

Apart from the aforementioned corrective measures, what is also needed to increase the quality of the Polish social assistance system is a greater openness towards and incentivization (legal, financial, organizational, media-related, etc.) of specific and innovative measures. These measures often have a high probability of failure, and will often be limited in nature and have local reach only, but they can solve certain problems more effectively and efficiently, and not only on a micro-scale. An example of such an initiative is undoubtedly the 'Mateusz' Association for Prevention and Rehabilitation, which has been operating in Torun for over ten years (Piątek, 2018a, p. 182). 


\section{The 'Mateusz' Re-adaptation Centre as the herald of the missing link in the post-release assistance in Poland}

The 'Mateusz' Association for Prevention and Rehabilitation was registered in Torun on 6 August 2009, and towards the end of that month the 'Mateusz' Re-adaptation Centre was established. This Centre has served as a refuge for individuals who have served time in Polish prisons, many of whom have previously undergone addiction treatment. The main tasks of the Centre include prevention (i.e., preventing reoffending) and rehabilitation (i.e., re-assimilating the individuals into society, understood narrowly as the community of the Centre's residents, more broadly as the local community, and generally, as the society as a whole). The rehabilitation process takes place through social re-adaptation, i.e., an individual effort on the part of the beneficiary, which enables adjustment to the surrounding environment, and social reintegration, i.e., extraordinary engagement of the (immediate and more distant) environment to increase the probability of successful rehabilitation.

The Re-adaptation Centre in Torun is only for men, the majority of whom are alcoholics before, during, or after treatment. In many cases, they are former prisoners convicted of various offences, including murder. Some residents of the Mateusz Centre were previously incarcerated in mental institutions. All of them can be described as homeless people, lost souls who suffer from health problems (emotional issues in particular), and who come mainly from Torun and other regions in Poland. These people most frequently come to 'Mateusz' straight 'from the street'; some of them are referred by probation officers; and recently, there have been cases of people who have learned about the Centre in prison. The basic activities of the Centre (including strictly support-type measures) are outlined in its regulations, and consist of, amongst others, satisfying the residents' livelihood needs (housing, food, clothing, shoes, cleaning products); providing support for activities of daily living, daily care activities and dealing with personal matters; organizing occupational therapy programmes and improving fitness; satisfying religious and cultural needs; stimulating the establishment, maintenance and development of relationships with family and wider communities; taking activities that support the independence of the residents and their employment; covering expenses for indispensable personal belongings (in the case of individuals with no personal income at all) for an amount not exceeding 20-30 per cent of the permanent benefit, contacting psychologists/therapists, etc. (Regulamin).

The establishment and development of the Centre were made possible due to extensive lobbying activities, as a result of which (amongst other forms of support) the city of Torun donated a suitable building for use by the Association. Moreover, the Mayor of Torun has visited the Centre on numerous occasions, as have several other local, regional and national politicians, as well as the Commissioner for Human Rights, numerous professors, students, journalists, and other persons. Further ideas currently being studied aim at stabilizing the Mateusz Centre's situation by including its funding requirements in the local post-release assistance system, the technicalities of which are being discussed through public debates and discussions organized by the Centre's friends and supporters. 
The successes of 'Mateusz', as evidenced by the fact that over one hundred and seventy individuals have resided there over the years, none of whom have returned to prison and almost all of whom have managed to lead successful personal and professional lives, contributed to the opening in June 2017 - in the city of Grudziądz - a 'clone' of the Mateusz Centre. This new centre targets women because there is a prison for women in Grudziądz, and the local municipal authorities actively involved themselves in the initiative to establish a facility similar to the one located in Torun.

\section{The 'Dabrowski method'}

The key person in 'Mateusz' is Waldemar Dąbrowski. He is the man behind the idea of both the Association for Prevention and Rehabilitation and the Re-adaptation Centre in Torun, and their founder. He serves as the CEO of the Association and as manager of the Centre. The latter position, in particular, involves arduous daily work, consisting of planning all the activities, seeking financial and human resources necessary for these undertakings, making many important (as well as routine) decisions on a daily basis, overseeing the manner of implementing them, representing the Centre externally, preparing various documents, and so on. Dąbrowski also performs a number of other functions in the Centre, such as preparing the accounts, doing physical work, acting asdriver, etc., but, above all, he performs many key tasks of a subject-matter expert. For example, he searches for potential future residents of the Centre by visiting prisons and other rehabilitation facilities, and conducts the initial interviews with individuals seeking support in order to decide whether to accept them. Since he lives on the premises of the Centre, he holds regular meetings with all the residents (individually and collectively), and also searches for jobs and medical treatment for them, and organizes meetings with members of their families. Furthermore, he establishes contact and develops cooperation with representatives of authorities at all levels, as well as with the world of science (e.g., professors, students) and mass media (Piątek, 2017, pp. 358-359).

The motivation behind the 'Dąbrowski method' are his own life experiences, such as alcoholism, his personal competence acquired during multiple alcohol-abuse treatment therapies, and his decade-long experience in managing the Mateusz Centre. The essence of the method comes down to several elements that are strongly interconnected and mutually reinforceable. These include:

1) Identification with the patients, both during group therapy (referred to as 'community') and in everyday conversations;

2) Honest dialogue with the patients, using their language, which establishes the necessary credibility;

3) 'Working with emotions', which allows for 'broken feelings', anger, sense of harm, injustice, abandonment, etc. to be addressed;

4) Delaying the confrontation with the social reality, which is particularly significant in the case of people who have lived in isolation for several years (sometimes over ten, or even twenty, years); 
5) Satisfying the residents' immediate material needs (housing, food, clothing, etc.) and other needs (cultural, social, physical exercise needs, etc.);

6) Supporting the residents to find work, professional therapy and medical assistance;

7) Creating suitable conditions for meetings with close relatives (family) and representatives of the local community;

8) Lobbying the outside world both directly and through the media (ibid., pp. 360-361).

\section{Elements of the initial post-release assistance programme and positive adaptation}

In searching for the answer to the question 'How can the Mateusz Re-adaptation Centre satisfy the definition of the missing link in the post-release assistance system in Poland?', the first statement that comes to mind is that a network of such centres could constitute the initial post-release assistance, just as with premedical first aid. These centres, performing the function of 'liberty sluices', would relatively painlessly secure the initial contact with the outside world, and thus limit the risk factors associated with contact with criminals and alcohol. Suitable conditions for starting preliminary treatment would be created, and the residents of such facilities could expect support from social assistance facilities, benefits or other types of allowance from labour offices, or any other form of assistance (e.g., medical, educational, etc.) (ibid., p. 367).

Moreover, Mateusz-type centres would create the conditions for a phenomenon referred to as 'positive adaptation', which can be defined as the process of successful adaptation to new circumstances outside of prison; such adaptations require quality transformations in relation to the various functions and psychosocial characteristics of an individual. In practice, positive adaptation is characterized by the following:

1. Clear and simple rules that leave no doubt as to the necessity of behaving in line with those rules, such as: giving up the consumption of alcoholic beverages and the use of psychoactive substances (either on the premises of the centre or outside) completely, eliminating verbally and physically abusive behaviour, establishing a polite manner of communication/truthfulness, etc.

2. An individual approach, which refers to adjusting the subject and form of support to the needs of a particular individual, his/her level of awareness, readiness for change and the degree of determination to leave one's comfort zone. In the Mateusz Centre, this approach is applied from day one, when Waldemar Dąbrowski speaks directly with all aspiring residents. Following admission, the residents have the possibility of contacting the Centre manager virtually every day, both during work (carried out jointly) and as part of longer (therapeutic) consultations.

3. Small number of residents of the same gender: Less than twenty men at most live in the Centre on a regular basis at any one time. This fosters a strengthening of interpersonal relationships, supports everyday direct contact, and creates a distinctive atmosphere of homeliness. 
4. Activation of the residents, which at 'Mateusz' has two dimensions: firstly, every person living at the Centre, within the scope of his abilities (strengths, skills and time), gets involved in the functioning of the residence and in the work associated with the everyday rhythm of its residents, and cooperates in a friendly manner to solve problems; secondly, every beneficiary of the Mateusz Centre works (or actively looks for a job) and, if possible and necessary, participates in various forms of therapy outside the Centre.

5. Special personality traits of the person managing the centre: these are shaped on the basis of life experiences (alcoholism, psychoactive substance addiction, imprisonment, homelessness, etc.) and/or acquired education in the area of psychology, pedagogy, sociology, rehabilitation, or in the area of social policy, social work, management, etc., which are connected with aptitudes that support the manager's credibility.

6. Special behaviour of the person managing the centre: This includes communicating with the residents using simple language, taking into account the perceptive capabilities of the residents, maintaining daily contact and observing the residents closely, paying close attention to their needs and being open to their requests, creating conditions that foster direct conversations, ensuring full acceptance and mutual respect, and relying on the resources, values and broadly understood capabilities of the residents" (ibid., pp. 367-368).

\section{Theoretical base No 1 - 'resilience'}

The essence of the 'Dąbrowski method' and the characteristics of positive adaptation are very well illustrated by the 'resilience' concept, which was introduced to the area of social sciences by pioneers in research on the development of children living in unfavourable conditions (primarily psychologists, paediatricians, sociologists and social workers). This concept is nowadays the subject of an interesting debate surrounding the definition of 'resilience', the conceptual range of the terminology used and its operationalization, and the method of measuring key variables (Luthar et al., 2000; Werner, 1994, 2000, as cited in Borucka \& Ostaszewski, 2008).

In literal translation, 'resilience' is elastyczność (flexibility), prężność (springiness), giętkość (suppleness), odporność (resistance), zdolność do regeneracji sit (ability to regenerate), and refers to a set of capabilities that allow an individual to handle a high level of stress and psychological trauma resulting from illness, death of a close relative, loss of a job, etc. What is important here is that 'resilience':

- focuses on investigating the phenomenon of proper functioning by certain individuals despite unfavourable living conditions, obstacles in life and/or traumatic events,

— is described as the ability of a person to 'bounce back'; one develops this ability by experiencing various difficulties in life and facing threats to fundamental values, such as: life, family, health, etc.

- appears when we face these events and have various experiences that enable us to obtain the necessary resistance resources, amongst which of crucial importance is the 
ability to distance oneself from negative experiences and overcome them (Piątek, 2018b, pp. 92-93).

Negative experiences are overcome by eliciting positive emotions which, in turn, trigger a spiral of positive processes, such as:

- the ability to create realistic plans and take steps to execute them,

- a positive image of oneself and a belief in one's capabilities,

- the ability to deal with strong emotions and impulses,

- building supportive relationships with other people (Borucka \& Ostaszewski, 2008). The example of Waldemar Dąbrowski can serve as a model for an analysis of 'resilience' in the form of the following stages:

1. Occurrence of risk factors: non-specific ones (loss of parents, the function of the father is taken over by an elder brother), and specific ones (success in sports or financial success).

2. Life difficulties, such as alcoholism, which pose a threat to fundamental values, such as life and health.

3. Experiencing suffering confronted with this risk and taking corrective actions (therapy, renovating barracks-like shelters, establishing and running the Mateusz Centre).

4. Development of the necessary resistance resources in the form of distancing oneself from negative experiences and evoking positive emotions in oneself.

5. Ability to look at one's experiences from a new perspective and maintaining hope, which triggers a spiral of positive processes (Piątek, 2018b, pp. 98-100).

While being treated for his own alcoholism, Dąbrowski established the 'Mateusz' Re-adaptation Centre where not just him, but others needing such support are also treated. "Apart from the ability to feel positive emotions, extreme resistance, i.e., 'resilience', is composed of the following elements: the ability to create realistic plans and take steps to execute them, a positive image of oneself and belief in one's capabilities, the ability to deal with strong emotions and impulses (although he [i.e., Dąbrowski] often gets tears in his eyes when mentioning various events in his life), and building supportive relationships with other people, which enabled him to create a facility that appears to be 'the missing link' in social assistance in Poland" (ibid., p. 100).

\section{Theoretical base No 2 - 'empowerment'}

In recent years, there has been a growing interest in the concept of 'empowerment', from its practical application by social workers, to employee management strategies in enterprises and branches of international institutions, to scientific papers and research. The concept of 'empowerment', which stems from research and literature published in the English language, has no proper equivalent in the Polish language and is translated into Polish as: upodmiotowienie, uwtasnowolnienie, upetnomocnienie, umacnianie, wzmacnianie, uprawomocnienie, uwtaszczenie, emancypacja, budowanie świadomości i pewności siebie, niezależności, zaufania, solidarności, aktywności, etc. In the Polish and foreign literature, there are numerous definitions and interpretations of 'empowerment', and one of the most 
interesting ones can be found in the documents of the Social Development Commission, in which it is conceptualized as "an emancipation process in which the disadvantaged are empowered to exercise their rights, obtain access to resources and participate actively in the process of shaping society and making decisions." (Luttrell et al., 2007, p. 2).

The active social policy implemented in Poland for over a decade is located, according to Marek Rymsza and Arkadiusz Karwacki, somewhere between two opposite poles (models); the first one is 'empowerment', i.e., the empowerment of individuals who are not independent - financially or otherwise - and their inclusion in the mainstream of social life, resulting in their having a stronger feeling of agency and regaining control over their lives; the second one is 'underclass' management, i.e., the management of people who are permanently assigned - in social and economic terms - to the category of customers/ beneficiaries of social assistance and increasing the level of their employability, assistance in this case mainly coming down to their reintegration into the world of employment (Rymsza \& Karwacki, 2017, pp. 39-40).

The 'Mateusz' Re-adaptation Centre represents - in terms of its assistance measures - the 'empowerment' model mainly because it was founded by a nongovernmental organization (the 'Mateusz' Association for Prevention and Rehabilitation), and is managed by a local individual (Waldemar Dąbrowski). This is manifested at three key levels of 'activation policy':

- the philosophy and axiology of activating support,

- the organization of the system and its management,

- the methodology of the activation work (direct contact with the customer).

As regards the philosophy and axiology of the support provided by the Mateusz Centre, they are included in the key objective of counteracting the problem of the exclusion and social marginalization of individuals released from prison. This objective is met through the inclusion of the Centre's residents in the mainstream of social life:

- externally (through professional work and therapy),

— internally (through work on the premises of the Centre).

As regards activation organization and management, various types of co-management elements are used at the Mateusz Centre. These take the form of making joint decisions on matters that are meaningful for the functioning of the Centre, while simultaneously limiting interference in the life of its beneficiaries and guaranteeing them influence on the organization of support, which leads to their empowerment.

Finally, as regards the methodology of support in the 'empowerment' model, the residents of the re-adaptation centre are treated as participants in a specific social ecosystem that constitutes a living environment and encompasses mainly the centre's residents, but also the involved representatives of the local community, businessmen, representatives of aid organizations, authorities (at various levels), therapists, researchers, students and doctoral students, etc. The Centre is also visited by the beneficiaries' family members: their wives, siblings, children, etc. This ecosystem also encompasses the workplaces of ex-prisoners, as well as external therapeutic facilities and other institutions, such as medias/sports institutions, etc. 


\section{The 'Mateusz' social laboratory}

Ten years of operation of the 'Mateusz' Re-adaptation Centre, over one hundred and seventy non-recidivist beneficiaries, support from hundreds of people for its activities, huge interest by the mass media, systematic cooperation with prisons and higher education institutions, multiple published articles and several diploma theses on 'Mateusz' (defended in various academic centres in Poland), support from local and regional authorities, interest by the Poland's Parliament and Ministry of Justice, etc. — these and many other factors contributed to the idea of the 'Mateusz' Social Laboratory, which it is aimed will be a simple route to using the experiences of 'Mateusz' in the development of a legal basis for the reform of the post-release assistance system in Poland towards the 'empowerment' model while taking into consideration the conclusions drawn from the 'resilience' concept.

The 'Mateusz' Social Laboratory is a social space where scientific research will be conducted using methods, techniques and research tools that are appropriate for solving a scientific problem, in the first stage without attempting to modify the space, and in the second stage by modifying the space on the basis of the research. The following entities/ individuals offered to support the experiment: the Province (Voivodeship) Marshal, City Mayor, representatives of the Municipal Family Support Centre (Miejski Ośrodek Pomocy Rodzinie), representatives of academic centres in Torun, Bydgoszcz, Warszawa, Białystok, Słupsk, Kraków, Rzeszów, Zielona Góra, as well as numerous therapists, local businessmen, and many other people.

The two- or three-year-long laboratory in Torun will have two components. The first one is the operation of the Centre itself - securing all its needs in terms of infrastructure, utilities, food, clothing, shoes, means of transport, sanitary products, medical/therapeutic/ educational/cultural resources, etc., at a level that would be expected from all the facilities of the future 'Mateusz Network'. The second component is systematic scientific research, conducted by professional researchers on the premises of the Centre with full access to the Centre, using adequately selected and prepared methods, techniques and research tools. The initial proposal includes:

- two general research tasks, i.e., monitoring the daily operation of the Centre and studying the effectiveness of the rehabilitation process taking place at 'Mateusz',

- three general scientific problems: 1) What is the Centre's recruitment process? 2) How does the Centre operate (in various areas) on a daily basis? 3) What does life look like for residents after they have left the Centre?

- general methodological assumptions, e.g., research methods (mainly qualitative ones like an experiment), research techniques (review of secondary sources, observations, interviews, surveys, tests, etc.), research tools (interview and survey questionnaires, scenarios of interviews and observations, etc.).

The first stage of implementing the 'Mateusz' Social Laboratory has already been completed; it involved preparing and discussing the overall concept over the years 2014-2019 through: 
- a discussion of the basics of the concept within a group comprising Waldemar Dąbrowski's closest associates from the therapeutic, academic, penitentiary, local government circles, etc.,

- lobbying at the city, province and national levels (meetings with ministers, province marshals, city mayors, local authority representatives, representatives of aid organizations, third-sector organizations, universities, mass media, local business, etc.),

- debates at the parliamentary level: in 2015, during meetings with two senate committees (to provide information about 'Mateusz'), and in 2018, at a meeting of the parliamentary prison system group (detailed discussion in the presence of representatives from the relevant ministries),

- the submission in February 2019 of a request to establish and finance the laboratory to the Director of the Department of the Justice Fund ${ }^{2}$ of the Ministry of Justice, and its re-submission in December 2019 to the Deputy Minister of Justice.

We are currently awaiting the formulation of the criteria for a tender (within the framework of the Justice Fund) with respect to 'soft' grants that enable the carrying out of scientific research with the participation of the relevant stakeholders, and then the definition of the tender process and completion of the selection process. Once the grant has been obtained (this is not guaranteed), the conditions for implementing the 'Mateusz' Social Laboratory will be put in place.

\section{Conclusion}

The ten years of operation of the 'Mateusz' Re-adaptation Centre constitute a period of growth, resulting in the existence of two facilities today (in Torun and in Grudziądz), and promotion of the Centre in the city, in the province, nationally and, increasingly, abroad. This has also, however, been a time of unresolved problems which have hindered the Centre's stabilization and the process of improving the effectiveness of the Polish post-release assistance system.

The probable cost of a two-year operation of the 'Mateusz' Social Laboratory is around PLN 1 million, and the numerous obstacles that we face on the road to its implementation prevent us from being too optimistic about its implementation.

\section{References}

Borucka, A., \& Ostaszewski, K. (2008). Koncepcja resilience. Kluczowe pojęcia i wybrane zagadnienia. Medycyna Wieku Rozwojowego [Developmental Period Medicine], 12, 587-597.

Frysztacki, K., \& Piątek, K. (2017). Problematyka pracy socjalnej w perspektywie socjologii i polityki społecznej. Wydawnictwo Edukacyjne AKAPIT.

2 The Justice Fund is the state's special purpose fund. Its mission and objectives are to assist crime victims and witnesses, prevent crime, and provide post-release assistance. 
Kaźmierczak, T. (2000). Pomoc społeczna. In Encyklopedia Socjologiczna. Oficyna Naukowa.

Luthar, S. S., Ciocchetti, D., \& Becker, B. (2000). The Construct of Resilience: A Critical Evaluation and Guidelines for Future Work. Child Development, 71, 543-562.

Luttrell, C., Sitna, Q., Scrutton, C., \& Bird, K. (2007). Understanding and operationalising empowerment. Overseas Development Institute.

Piątek, K. (2017). Ośrodek Readaptacyjny „Mateusz” — coaching, terapia, mentoring, itd.?

W poszukiwaniu istoty nowego podejścia do wspierania osób opuszczających zakłady karne w Polsce. In B. Kromolicka, A. Jarzębińska (eds.), O (wyzwaniach) wspótczesnej pracy socjalnej. Nowe problemy - zmiana — transgresja. Uniwersytet Szczeciński.

Piątek, K. (2018a). Poszukiwanie nowych rozwiązań w pomocy społecznej w kierunku modelu empowerment - na przykładzie Ośrodka Readaptacyjnego „Mateusz” w Toruniu. In M. Bednarski, \& Z. Wiśniewski (eds.), Polityka spoteczna w Polsce. Osiagnięcia $i$ wyzwania. Centrum Partnerstwa Społecznego „Dialog” im. A. Bączkowskiego, Instytut Pracy i Spraw Socjalnych.

Piątek, K. (2018b). Przydatność koncepcji resilience w reformowaniu pomocy społecznej w Polsce - przypadek stowarzyszenia „Mateusz”. Problemy Polityki Spotecznej. Studia $i$ Dyskusje [Problems of Social Policy. Studies and Discussions], 41.

Regulamin Ośrodka Readaptacyjnego „Mateusz” w Toruniu [Regulations of the 'Mateusz' Re-adaptation Centre in Toruń].

Rymsza, M. (2010). W stronę pracy socjalnej i działań aktywizujących w pomocy społecznej. Problemy Polityki Społecznej. Studia i Dyskusje [Problems of Social Policy. Studies and Discussions], 13-14.

Rymsza, M., \& Karwacki, A. (2017). Między podejściem empowerment a zarządzaniem underclass. Dwa modele aktywizacji w polityce społecznej. In A. Karwacki, A. Rymsza, M. Gąciarz, T. Kaźmierczak, \& B. Skrzypczak, Niezatrudnieniowe wymiary aktywizacji. W stronę modelu empowerment. Wydawnictwo Naukowe Uniwersytetu Mikołaja Kopernika.

Służba Więzienna: Statystyka roczna [Prison Service: Annual statistics] (2018). http:// sw.gov.pl/pl/o-służbie-więziennej/statystyka/statystyka-roczna/.

Szumlicz, T. (2002). O systemie zabezpieczenia społecznego — podobnie i inaczej. In J. Auleytner (ed.), O roztropna politykę społeczna. Polskie Towarzystwo Polityki Społecznej. Trawkowska, D. (2010). Czy był to „milowy krok”, czy możemy raczej mówić o „kroku milowym, którego nie było"? Krótkie podsumowanie debaty w ramach Forum na temat pomocy społecznej. Problemy Polityki Spotecznej. Studia i Dyskusje [Problems of Social Policy. Studies and Discussions], 13-14.

Werner, E. E. (1994). Overcoming the Odds. Journal of Developmental and Behavioral Pediatrics, 15(2), 131-136.

Werner, E. E. (2000). Protective Factors and Individual Resilience. In J. P. Shonkoff, \& S. J. Meisels (eds.), Handbook of Early Childhood Intervention. (115-132). Cambridge University Press. 